\title{
Kemampuan Penalaran Matematis Siswa dalam Memecahkan Masalah Matematika pada Saat Pembelajaran Daring
}

\author{
Nastiti Kusumaningtyas ${ }^{1}$, I. Nengah Parta ${ }^{2}$, Hery Susanto ${ }^{3}$ \\ 1, 2, 3 Program Studi Magister Pendidikan Matematika, Universitas Negeri Malang, \\ Jl. Semarang No. 05, Malang, Indonesia \\ nastitikusumaningtyas@gmail.com
}

\begin{abstract}
This study aims to describe the mathematical reasoning ability of junior high school students in solving quadrilateral problems when learning is online. The study was attended by 20 students of class IX C of SMP Negeri 1 Kencong. Furthermore, 6 samples were selected consisting of 6 subjects, namely two subjects who had high mathematical ability, two subjects who had a moderate mathematical ability, and two subjects who had low mathematical ability to then conduct online interviews using the WhatsApp application. The research instrument in this study was a quadrilateral mathematical problem-solving test and interview guidelines. The results showed that subjects with high mathematical abilities also had high mathematical reasoning abilities. Subjects who have moderate mathematical abilities also have moderate mathematical reasoning abilities. Students with low mathematical abilities also have low mathematical reasoning abilities. In addition, students with high mathematical reasoning abilities can provide more than one answer in solving problems.
\end{abstract}

Keywords: ability, reasoning, problem solving, quadrilateral

\begin{abstract}
Abstrak
Penelitian ini bertujuan untuk mendeskripsikan kemampuan penalaran matematis siswa SMP dalam memecahkan masalah segiempat pada saat pembelajaran dilakukan secara daring. Penelitian diikuti oleh 20 siswa kelas IX C SMP Negeri 1 Kencong. Selanjutnya dipilih 6 sampel yang terdiri dari 6 subjek yaitu dua subjek yang mememiliki kemampuan matematis tinggi, dua subjek yang mempunyai kemampuan matematis sedang, serta dua subjek yang mempunyai kemamuan matematis rendah untuk kemudian dilakukan wawancara secara daring menggunakan aplikasi Whatssapp. Instrumen penelitian dalam penelitian ini adalah tes pemecahan masalah matematika segiempat dan pedoman wawancara. Hasil penelitian menunjukkan bahwa subjek dengan kemampuan matematika tinggi juga memiliki kemampuan penalaran matematis yang tinggi. Subjek yang memiliki kemampuan matematika sedang juga memiliki kemamuan penalaran matematis sedang. Siswa dengan kemampuan matematika rendah juga memiliki kemampuan penalaran matematis rendah. Selain itu, siswa dengan kemampuan penalaran matematis tinggi bisa memberikan lebih dari satu jawaban dalam memecahkan masalah.
\end{abstract}

Kata kunci: kemampuan, penalaran, penyelesaian masalah, segiempat

Copyright (c) 2021 Nastiti Kusumaningtyas, I. Nengah Parta, Hery Susanto

$\triangle$ Corresponding author: Nastiti Kusumaningtyas

Email Address: nastitikusumaningtyas@gmail.com (Jl. Semarang No. 05, Malang, Indonesia)

Received 06 September 2021, Accepted 01 October 2021, Published 29 December 2021

\section{PENDAHULUAN}

Matematika merupakan ilmu yang memilii peran penting dalam setiap aspek kehidupan masyarakat. Alasan matematika dianggap penting karena matematika menjadi salah satu mata pelajaran yang harus dipelajari pada setiap jenjang sekolah. Standar matematika di sekolah meliputi standar isi dan standar proses. Standar proses matematika terdiri dari pemecahan masalah, penalaran, serta komunikasi. Ketika proses pembelajaran matematika, pengaitan antara pengetahuan yang telah dielajari dengan situasi saat ini akan sering terjadi. Pengaitan terjadi secara spontan atau dengan melalui perbaikan skenario yang telah dimiliki oleh siswa. Keteraturan bentuk informasi yang baru dan pengetahuan yang telah dimiliki akan selalu diidentifikasi dalam proses pengaitan (Parta, 2016) 
Salah satu tujuan matematika yang termasuk dalam standar proses adalah penalaran. Penalaran juga termasuk dalam tujuan dari pembelajaran matematika yaitu memakai penalaran pada bentuk serta sifat, dapat melaksanakan manipulasi matematika untuk membuat generalisasi serta menyusun fakta, ataupun memaparkan gagasan serta pernyataan matematika, (Standar Isi dan Standar Proses permendiknas No. 22 Tahun 2006). Dalam kegiatan pembelajaran pemecahan masalah perlu diutamakan karena dengan sering menghadapi pemasalahan matematika siswa akan terdorong untuk menggunakan nalarnya sehingga penalaran siswa dapat terasah dengan baik (Suciati, 2015).

Dalam Peraturan Menteri Pendidikan dan Kebudayaan Republik Indonesia Nomor 21 tahun 2016 tentang standar isi pendidikan dasar dan menengah dijelaskan bahwa salah satu kompetensi yang harus dimiliki siswa dalam pembelajaran matematika yakni menjelaskan pola dan menggunakannya untuk memprediksi kecenderungan atau memeriksa kesahihan argumen. Pada Kurikulum 2013 revisi 2016 siswa diharuskan untuk bisa menerapkan konsep untuk memecahkan permasalahanpermasalahan dan juga bisa untuk bernalar dan berpendapat. Sehingga setelah belajar matematika siswa memiliki kemampuan menalar yang bisa digunakan dengan baik.

Berkaitan dengan penalaran, National Council of Teacher of Mathematics (NCTM, 2000) mengatakan bahwa dalam pelaksanaan kegiatan belajar mengajar matematika, guru memberi perhatian lebih terhadap 5 kemampuan matematis, diantaranya: (1) pemecahan masalah, (2) penalaran, (3) komunikasi, (4) koneksi, dan (5) representasi. Oleh karena itu, guru mengambil peran penting dalam memunculkan kemampuan penalaran matematis pada diri siswa baik dalam bentuk metode pembelajaran yang digunakan, maupun dalam penilaian pembelajaran seperti membuat soal yang membangkitkan kemampuan matematis dalam diri siswa. Penalaran yakni suatu proses ataupun suatu kegiatan berpikir untuk menarik suatu kesimpulan ataupun membuat suatu pernyataan baru yang benar serta bersumber pada pada sebagian pernyataan yang kebenarannya sudah dibuktikan ataupun diasumsikan sebelumnya. Kemampuan penalaran matematis harus di kembangkan oleh siswa agar mampu memecahkan masalah, menilai secara kritis dan mengungkapkan ide-ide secara logis (A. Hidayat, 2019). Salmina juga menyatakan kemampuan penalaran matematis yaitu kemampuan menghubungkan permasalahan-permasalahan ke dalam suatu ide atau gagasan sehingga dapat menyelesaikan permasalahan matematis (Salmina, 2018). Sehingga pelajaran matematika dan penalaran matematis adalah dua hal yang berkaitan, yaitu menyelesaikan masalah matematis diperlukan penalaran dan kemampuan penalaran dapat diasah dari belajar matematika.

Indikator dari penalaran matematis adalah siswa mampu untuk mengajukan sebuah rencana penyelesaian, membuat manipulasi agar ia mampu menyelesaikan soal dengan mudah, memberikan alasan yang telah terbukti kebenarannya dan mampu mendukung pendapatnya dalam hasil pekerjaannya. Ario mengemukakan bahwa indikator penalaran diantaranya; memeriksa kebenaran dari suatu pernyataan, membuat perumpamaan dan generalisasi, menarik kesimpulan yang masuk akal, dan mengikuti aturan dari referensi (Ario, 2016). Indikator penalaran matematis diantaranya ialah memprediksi jawaban, membuat analogi, menarik kesimpulan, membuktikan pernyataan, serta 
melaksanaan perhitungan menurut aturan dan rumus tertentu (E. Rohaeti, 2019). Indikator penalaran menurut (Nurkhaeriyah T. S., 2018) diantaranya adalah membuat dan menguji kebenaran, memprediksi solusi, mengambil kesimpulan yang logis, dan membuat perumamaan dan generalisasi. Napitupulu, Suryadi, \& Kusumah (2016) mengatakan empat indikator untuk mengukur kemampuan penalaran matematis siswa, yaitu: (a) mampu membuat kesimpulan logis; (b) mampu memberikan penjelasan tentang bentuk, kondisi, properti, ikatan, atau pola yang ada; (c) mampu membuat dugaan disertai dngan bukti; dan (d) mampu menggunakan pola hubungan untuk menganalisis keadaan, membuat perumpamaan, atau menggeneralisasikan. Berdasarkan hal ini maka indikator penalaran matematis untuk memecahkan masalah matematika yang digunakan dalam penelitian ini ialah mengajukan dugan, melakukan manipulasi matematika, memberikan alasan logis dari pendapatnya, serta menarik kesimpulan.

Pemecahan masalah ialah salah satu kegiatan pada proses pembelajaran kepada anak sejak usia dini. Pemecahan masalah juga merupakan upaya yang dapat dilakukan untuk mendapatkan solusi dari masalah yang dihadapi melalui kemampuan kognitif, keterampilan, dan pengetahuan yang telah dimiliki sebelumnya (Hidayat W., 2018). Setiap kegiatan manusia selalu diliputi oleh pemecahan masalah baik itu dalam ilmu hukum, pengetahuan, bisnis, olah raga, industri kesehatan, dan sebagainya. Polya (How to Solve It: A New Aspect of Mathematical Method (Second Edition), 1973) menyatakan bahwa pemecahan masalah ialah cara untuk mencari penyelesaian dari suatu kesulitan untuk mencapai tujuan yang belum tercapai. Polya juga mengutarakan 4 tahapan yang praktis dan tersusun sistematis dalam memecahkan permasalahan matematika. Empat tahap dalam memecahkan masalah menurut Polya diantaranya : (1) memahami masalah, (2) melakukan rencana, (3) melakukan rencana penyelesaian masalah, dan (4) memeriksa kembali hasil yang telah diperoleh. Siswa yang menerapkan empat tahapan Polya berarti melakukan aktivitas yang melibatkan penyusunan konsep yang diharapkan siswa bisa memecahkan masalah secara terstruktur dan sistematis. Penalaran matematis siswa masih kurang di asah dengan baik maka perlu dilakukan analisa mendalam tentang kemampuan penalaran matematis siswa (Muharrom, 2014). Berdasarkan uraian yang telah disampaikan, maka proses penalaran matematis siswa dalam memecahkan masalah matematika perlu dikaji lebih lanjut. Tujuan penelitian ini adalah untuk mengetahui tingkat penalaran matematis siswa kelas IXC di SMP Negeri 1 Kencong. Hal ini dilakukan karena di sekolah tersebut guru ingin mengetahui kemampuan penalaran matematis siswa karena pada saat pembelajaran daring seperti saat ini sangat sulit untuk mengetahui kemampuan penalaran matematis siswa. Padahal mengetahui kemampuan penalaran matematis siswa sangat penting karena dapat membantu guru dalam memahami kemampuan siswa dalam belajar matematika.

\section{METODE}

Penelitian ini ialah penelitian deskriptif dengan pendekatan kualitatif dan bertujuan untuk mendeskrisikan kemampuan penalaran matematis siswa dalam memecahkan masalah matematika 
segiempat. Penelitian deskriptif adalah penelitian yang dimaksudkan untuk menyelidiki keadaan, kondisi atau hal lain-lain yang sudah disebutkan, yang hasilnya dipaparkan dalam bentuk laporan penelitian (Arikunto, 2013). Penelitian kualitatif memperoleh data dari penelitian berupa data wawancara, pengamatan, dan dokumen, menganalisis tulisan dan gambar; dan mengartikan inti dan pola yang terdapat di dalam data (Creswell, 2012). Penelitian deskriptif kualitatif adalah penelitian yang digunakan untuk meneliti masalah manusia dan sosial dimana peneliti akan melaporkan dari hasil penelitian berdasarkan laporan pandangan data dan analisa data yang didapatkan di lapangan, kemudian di deskripsikan dalam laporan penelitian secara rinci (Creswell, 2012). Oleh karena itu, penelitian ini menggunakan dokumentasi berupa hasil pekerjaan siswa dalam memecahkan soal yang digunakan untuk mengumpulkan data, menganalisis, dan mengartikan hal penting yang terdapat di dalam data.

Dalam penelitian ini diambil sampel sebanyak 6 siswa kelas IX C SMP Negeri 1 Kencong yang dipilih berdasarkan kemampuan matematika mereka yaitu siswa yang mempunyai kemampuan penalaran matematis tinggi, sedang, dan rendah. Pengambilan subjek penelitian dilakukan dengan melihat hasil ulangan harian matematika. Untuk subjek yang dilakukan wawancara dipilih berdasarkan hasil tes dan rekomendasi dari guru siswa-siswa yang bisa aktif untuk berkomunikasi menjawab pertanyaan. Hasil jawaban siwa akan dianalisis untuk menghasilkan gambaran yang jelas dan lengkap mengenai kemampuan penalaran siswa dalam memecahkan masalah segiempat.

Instrumen dalam penelitian ini adalah peneliti yang bertindak untuk mengamati, bertanya, dan mengambil data penelitian. Alat ukur yang digunakan dalam penelitian ini adalah dokumen soal dan pedoman wawancara. Soal tes berguna untuk mengukur kemampuan penalaran matematis dan bertujuan untuk mengetahui jawaban siswa apakah sudah mencapai tingkat penalaran matematis yang ditentukan. Pedoman wawancara berguna untuk mengkonfirmasi jawaban siswa. Siswa diberikan soal open ended untuk mengukur tingkat kemampuan penalaran matematis siswa. Berikutnya dipilih 6 siswa yang akan diwawancara, 2 siswa yang memiliki kemampuan matematis tinggi, 2 siswa yang memiliki kemampuan matematis sedang, dan 2 siswa yang memiliki kemampuan matematis rendah. Pengambilan data tes dilakukan secara daring pada hari Sabtu, 3 April 2021 pada saat jam mata pelajaran matematika di SMP Negeri 1 Kencong. Dan wawancara dilakukan pada 5 April 2021 secara daring melalui aplikasi Whatsapp.

\section{HASIL DAN DISKUSI}

\section{Siswa dengan Kemampuan Matematis Tinggi (ST1)}

Berdasarkan tes yang telah dilakukan, siswa dengan kemampuan matematis tinggi telah mampu menyelesaikan soal yang diberikan dengan baik dan benar sesuai Gambar 1. Subjek mampu membuat dugaan dengan baik, hal ini dapat dilihat dengan siswa yang menuliskan informasi tinggi tower pertama dan kedua yang diketahui di soal pada lembar jawaban. Ketika dilakukan wawancara, siswa menyampaikan bahwa selisih dari tower 1 dan tower 2 adalah 4 meter, maka siswa menduga 
Kemampuan Penalaran Matematis Siswa dalam Memecahkan Masalah Matematika pada Saat Pembelajaran Daring, Nastiti Kusumaningtyas, I. Nengah Parta, Hery Susanto

bahwa selisih tower 2 dan tower 3 juga 4 meter. Siswa juga sudah mampu melakukan manipulasi matematika dengan membuat perhitungan menggunakan x untuk merepresentasikan banyak persegi dan y persegi panjang. Manipulasi matematika yang telah dilakukan membantu siswa untuk menyelesaikan masalah. Siswa ini juga sudah mampu memberikan alasan dari penyelesaian yang telah dibuat. Hal ini didapat ketika dilakukan wawancara. Siswa dapat menjelaskan mengapa dia mendapat tinggi 31 meter untuk tower ke 3, karena selisih dari tower-tower tersebut 4 meter, dan tinggi tower kedua 27 meter maka tinggal ditambah dengan 4 meter, jadi 31 meter.

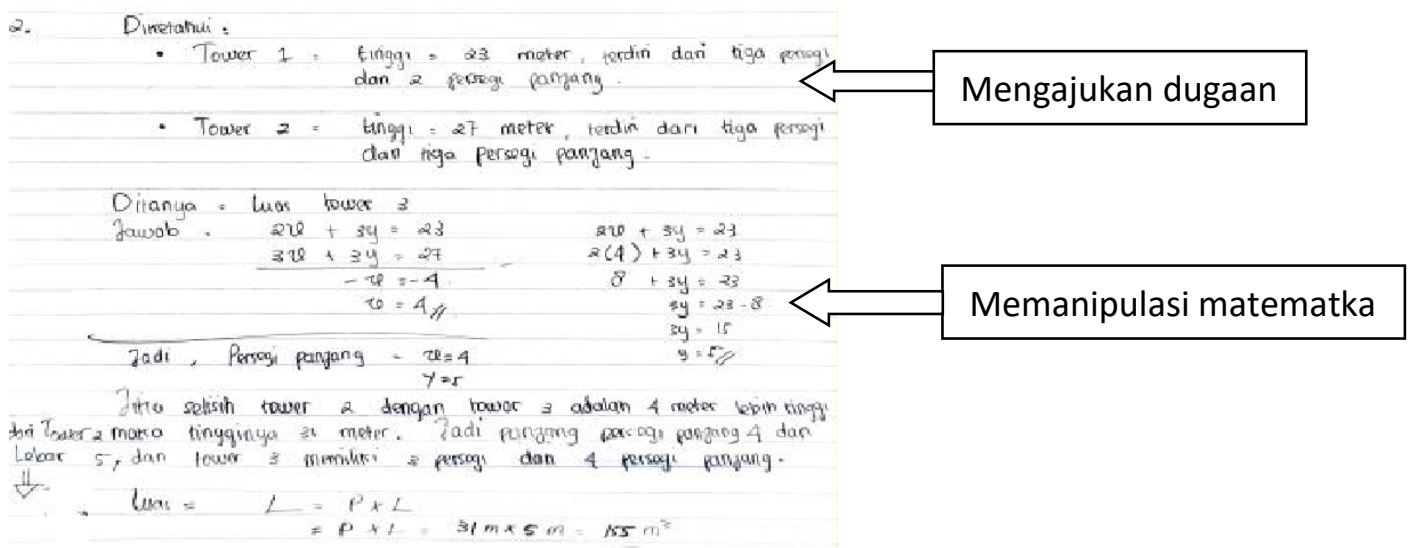

Gambar 1. Hasil Pekerjaan Siswa dengan Kemampuan Matematis Tinggi

Siswa juga mampu melakukan manipulasi matematika dengan baik. Hal ini dapat dibuktikan dari cara siswa menjabarkan langkah-langkah yang digunakan dalam menyelesaikan soal yang diberikan. Siswa juga sudah mampu untuk memberikan alasan dari jawaban yang diperolehnya. Siswa dapat menjelaskan secara rinci berapa banyak persegi dan persegi panjang pada tower ketiga. Siswa juga sudah mampu untuk menarik kesimpulan dari seluruh hasil pekerjaannya, siswa menyimpulkan bahwa tower ketiga terdiri dari 3 persegi dan 4 persegi panjang. Siswa juga mampu untuk menentukan luas tower ketiga yaitu $155 \mathrm{~m}^{2}$ setelah menemukan tinggi tower dan lebar tower.

\section{Siswa dengan Kemampuan Matematis Tinggi (ST2)}

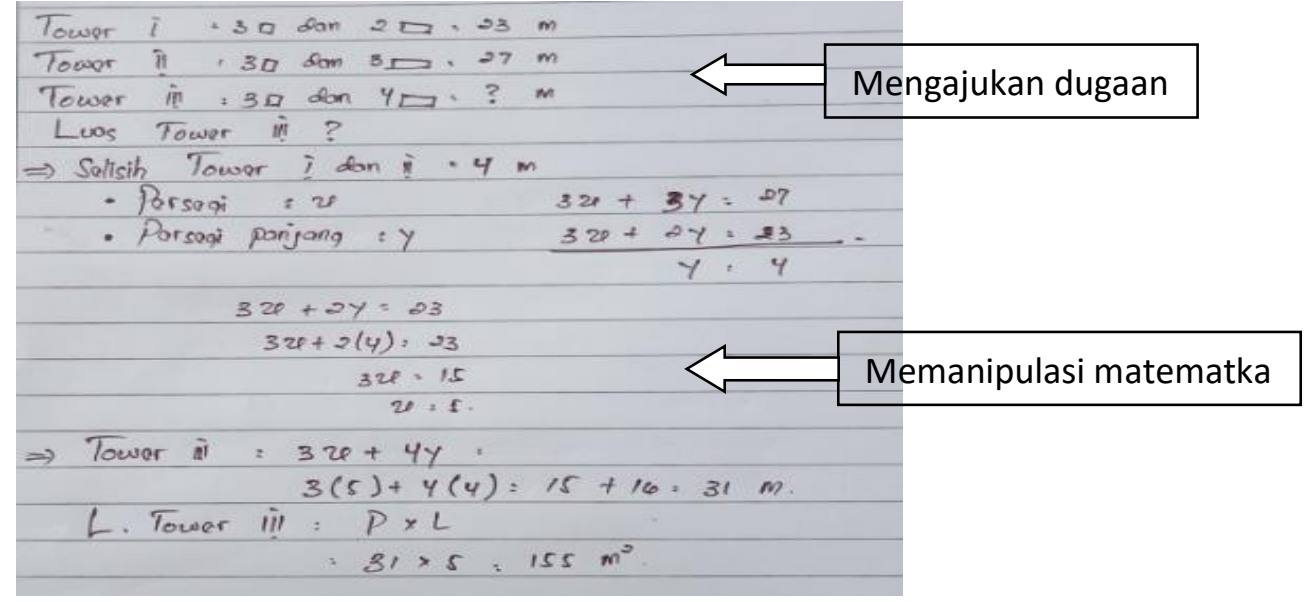

Gambar 2. Jawaban Siswa dengan Kemampuan Matematis Tinggi 
Berdasarkan gambar diatas, dapat dilihat bahwa siswa menuliskan tinggi tower terdiri dari bangun persegi dan persegi panjang. Dan siswa mengumpamakan persegi sebagai $x$ dan persegi panjang sebagai $y$. Dengan menggunakan eliminasi menggunakan sistem persamaan linear dua variabel, siswa mengetahui nilai dari $x$ dan $y$. Setelah mengetahui nilai $x$ dan $y$ siswa bisa mengetahui tinggi dari tower ketiga dan didapatkan tinggi tower ketiga $31 \mathrm{~m}$. Berdasarkan hasil wawancara siswa menyampaikan bahwa cara yang dia ketahui paling mudah untuk menentukan masing-masing panjang dan lebar persegi panjang adalah dengan menggunakan metode eliminasi. Pada indikator membuat dugaan, siswa sudah mampu membuat dugaan dengan benar. Hal ini dilihat dari hasil pekerjaan siswa pada lembar jawaban juga pada saat dilakukan wawancara siswa dapat menjelaskan secara runtut dan sesuai untuk informasi yang diketahui pada soal. Untuk indikator memanipulasi matematika, siswa sudah mampu melakukan manipulasi matematika dengan baik, siswa dapat mengaitkan materi lain dalam menentukan nilai $x$ dan $y$, yaitu materi sistem persamaan linear dua variabel. Pada indikator Memberikan alasan untuk penyelesaian yang telah dibuat, siswa mampu untuk memberikan alasan yang sesuai dengan materi yang telah dipelajari dan mengapa siswa menggunakan materi tersebut untuk menyelesaikan masalah. Pada indikator menarik kesimpulan, siswa sudah mampu menarik kesimpulan untuk penyelesain yang telah dibuat, siswa menarik kesimpulan saat dilakukan wawancara dikarenakan siswa lupa untuk menuliskan penarikan kesimpulan ada lembar jawaban. Siswa menarik kesimpulan dengan runtut dan dapat dipahami dengan mudah.

\section{Siswa dengan Kemamuan Matematis Sedang (SD1)}

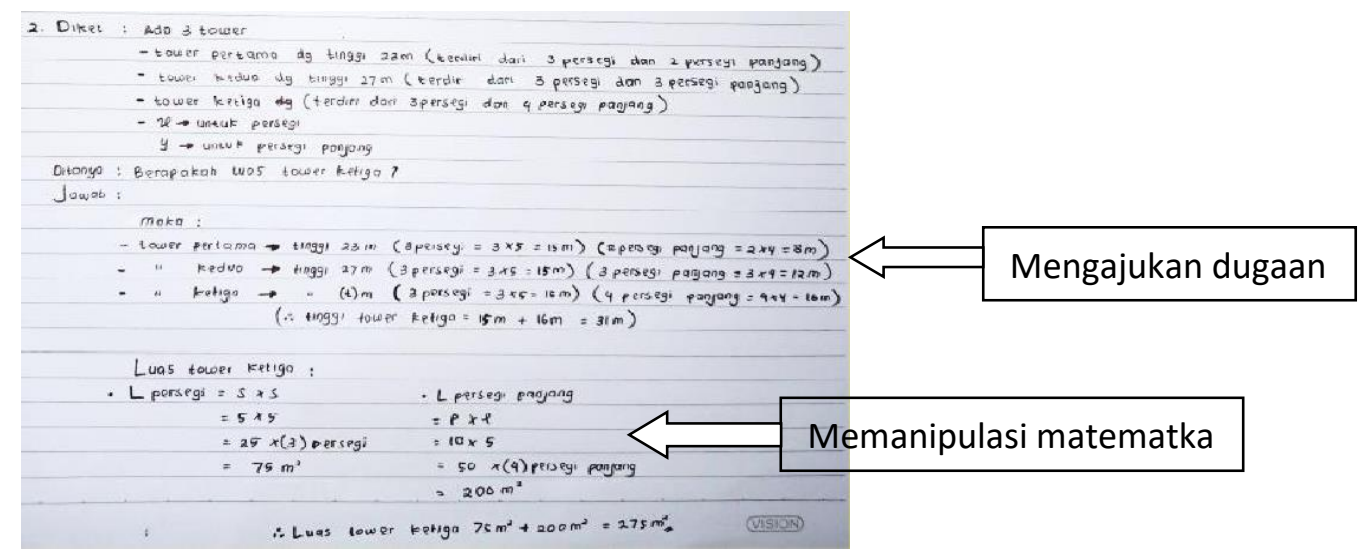

Gambar 3. Hasil Pekerjaan Siswa dengan Kemampuan Matematis Sedang

Hasil tes dan wawancara dari siswa dengan kemampuan matematis sedang dapat memecahkan masalah. Siswa mampu untuk membuat dugaan untuk masalah yang akan dikerjakannya. Siswa dapat menyampaikan hal yang diketahui dan ditanya pada soal dengan baik. Dalam membuat manipulasi matematika, siswa sudah membuat manipulasi matematika untuk mempermudah penyelesaian yang dikerjakannya tetapi manipulasi tersebut masih belum benar. Hal ini dapat dilihat dari siswa membuat ilustrasi tower pertama, kedua, dan ketiga berdasarkan banyak persegi dan persegi panjang. Untuk memberikan alasan dari pernyataan yang telah dibuat siswa masih merasa kesulitan, siswa hanya mengandalkan rumus yang telah diketahuinya. Hal ini diketahui pada saat wawancara siswa seringkali 
Kemampuan Penalaran Matematis Siswa dalam Memecahkan Masalah Matematika pada Saat Pembelajaran Daring, Nastiti Kusumaningtyas, I. Nengah Parta, Hery Susanto

bertanya apakah sudah benar pernyataan yang dikatakannya. Dalam menarik kesimpulan jawaban, siswa hanya membuat kesimpulan jawaban tanpa memberitahu tinggi dari tower dan terdiri dari berapa persegi dan persegi panjang tower tersebut. Tower kedua terdiri dari tiga persegi dan tiga persegi panjang. Karena banyak persegi pada tower pertama dan kedua sama sedangkan banyak persegi panjang pada tower pertama dna kedua memiliki selisih satu, maka siswa ini menganggap bahwa selisih banyaknya persegi panjang pada tower kedua dan ketiga juga satu. Jadi siswa mendapat kesimpulan bahwa pada tower ketiga terdapat tiga persegi dan empat persegi panjang dengan tinggi tower 31 meter. Setelah mengetahui tinggi tower ketiga, siswa langsung mencari luas dari tower. Untuk mencari luas dari tower, siswa mencari terlebih dahulu luas masing-masing ersegi dan persegi panjang. Didapatkan luas persegi adalah $25 \mathrm{~m}^{2}$ dan terdapat 3 persegi. Sedangkan luas persegi panjang adalah $50 \mathrm{~m}^{2}$ dan terdapat 4 persegi panjang. Jadi siswa menarik kesimpulan bahwa luas dari tower ketiga adalah $275 \mathrm{~m}^{2}$.

\section{Siswa dengan Kemamuan Matematis Sedang (SD2)}

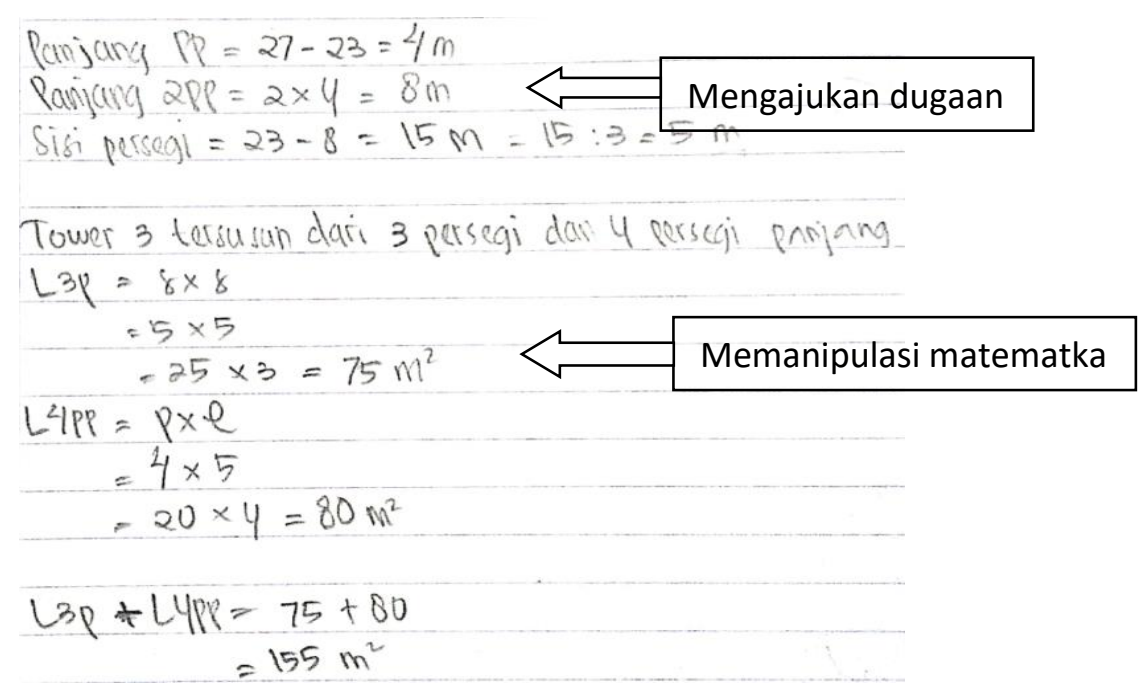

Gambar 4. Hasil Pekerjaan Siswa dengan Kemampuan Matematis Sedang

Berdasarkan penelitian, siswa dengan kemampuan matematis sedang (SD2) mampu membuat dugaan dalam menyelesaikan masalah. Hal ini dapat dilihat dari tulisan siswa yang menganalisis tinggi tower ketiga terdiri dari 3 persegi dan 4 persegi panjang. Siswa menemukan tinggi dari persegi panjang dengan mengurangi tinggi tower pertama dengan tinggi tower ketiga, untuk menegtahui sisi persegi siswa mengurangi tinggi tower kedua dengan panjang dua persegi panjang lalu dibagi tiga. Hal ini dilakukan karen asiswa mengetahui bahwa tower kedua tersusun dari 2 persegi panjang dan 3 persegi. Ketika dilakukan wawancara siswa juga mampu menyebutkan informasi yang diketahui dari soal. Pada indikator memanipulasi matematika, siswa mampu melakukan manipulasi matematika, namun pada saat memanipulasi matematika dapat dilihat bahwa siswa belum memahami soal, hal ini dilihat dari siswa yang tidak menemukan tinggi tower ketiga. Ketika wawancara siswa mampu untuk menerangkan bagaimana siswa tersebut menyelesaikan masalah, tetapi saat ditanya tentang tinggi tower siswa masih berpikir apa yang dilakukan untuk mencari tinggi tower ketiga. Pada indikator 
memberikan alasan, siswa masih kesusahan dalam memberikan alasan yang benar. Pada indikator menarik kesimpulan, siswa masih bisa menarik kesimpulan meskipun harus dibantu oleh peneliti. Siswa menarik kesimpulan dengan menjelaskan bahwa tower ketiga memiliki luas $155 \mathrm{~m} 2$ dan didapatkan dengan mengetahui luas persegi dan persegi panjang terlebih dahulu.

\section{Siswa dengan Kemampuan Matematis Rendah (SR 1)}

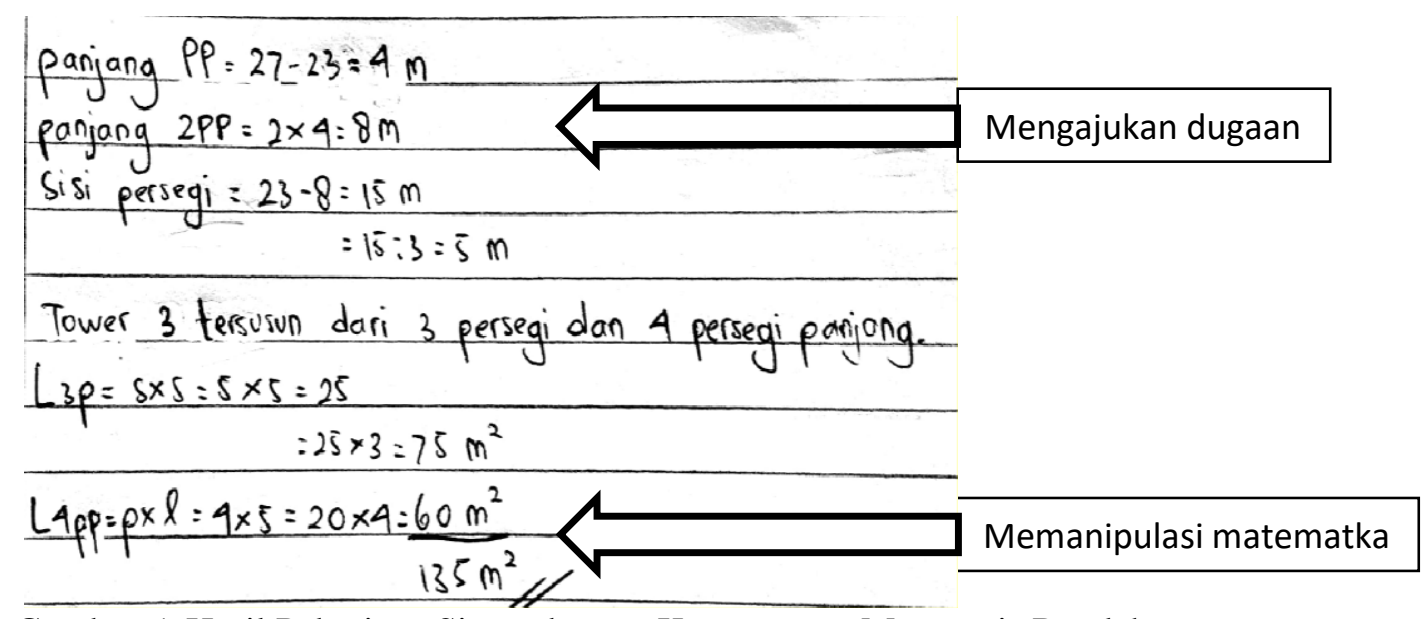

Gambar 5. Hasil Pekerjaan Siswa dengan Kemampuan Matematis Rendah

Berdasarkan penelitian yang telah dilakukan, hasil tes dan wawancara siswa dengan kemampuan matematis rendah siswa belum mampu memahami soal dengan benar. Siswa tidak bisa menyampaikan dengan runtut informasi yang diketahui ada soal. Akibatnya siswa belum bisa membuat dugaan yang benar untuk memecahkan masalah. Siswa secara terbata-bata menyebutkan informasi yang diketahui pada saat wawancara. Dalam membuat manipulasi matematika, siswa masih belum melakukan hal ini dengan baik, siswa hanya mengilustrasikan panjang dari persegi dan persegi panjang namun masih kurang benar. Siswa belum mampu menentukan tinggi tower yang ditanyakan. Untuk memberikan alasan dari pekerjaan yang telah dibuat siswa juga masih kesulitan. Dalam menentukan luas siswa juga masih melakukan kesalahan dalam perhitungan. Untuk memberikan alasan dari pernyataan yang telah dibuat, siswa juga belum mampu untuk memberikan pernyataan yang benar seain mengandalkan rumus. Untuk menarik kesimpulan siswa merasa tidak mampu melakukannya meskipun sudah dituntun oleh peneliti.

\section{Siswa dengan Kemampuan Matematis Rendah (SR 2)}

Siswa dengan kemampuan matematis rendah hanya mengerjakan soal yang diberikan tanpa adanya langkah-langkah penyelesaian. Hal ini dapat dilihat pada gambar 6 siswa tidak menuliskan informasi yang diketahui. Pada saat wawancara siswa mengatakan telah memahami soal tetapi masih belum memahami cara pengerjaan yang sesuai. Pada indikator mengajukan dugaan siswa dengan kemampuan matematis rendah siswa tidak membuat dugaan. Hal ini dapat dilihat pada gambar dimana siswa tidak melakukan dugaan mengenai tinggi tower kedua dan tinggi tower ketiga. Padahal pada soal ini dugaan sangat penting agar mampu mengetahui kemungkinan tinggi tower ketiga. Pada saat wawancara, siswa juga mengalami kesulitan saat ditanya mengenai dugaan. Untuk indikator 
Kemampuan Penalaran Matematis Siswa dalam Memecahkan Masalah Matematika pada Saat Pembelajaran Daring, Nastiti Kusumaningtyas, I. Nengah Parta, Hery Susanto

memanipulasi matematis siswa tidak menyampaikan bagaimana $x$ dan $y$ bisa muncul dan merepresentasikan apa. Ketika dilakukan wawancara siswa hanya menyebutkan bahwa $x$ merepresentasikan lebar dan $y$ merepresentasikan tinggi.

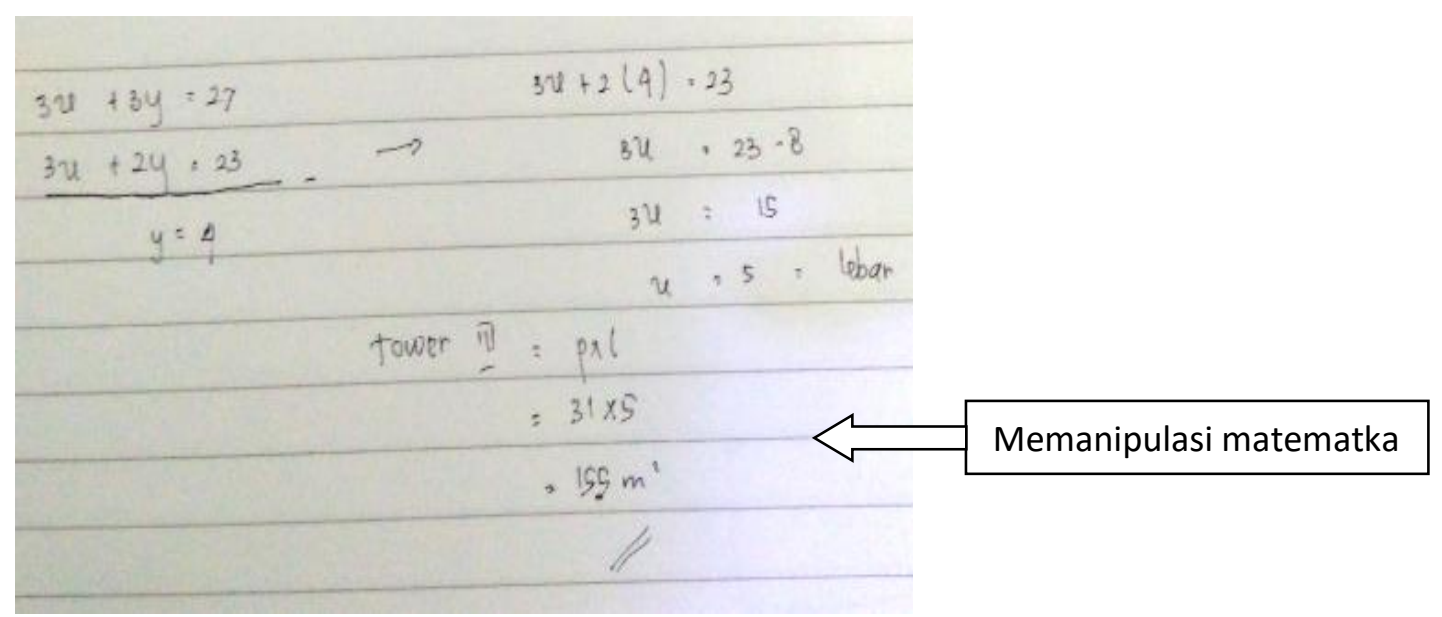

Gambar 6. Hasil Pekerjaan Siswa dengan Kemampuan Matematis Rendah (hanya melakukan manipulasi matematika)

Siswa tidak mencari tinggi terlebih dahulu tetapi langsung menemukan luas setelah menemukan panjang dan lebar dari tower ketiga. Seharusnya siswa terlebih dahulu mencari tinggi dari tower ketiga. Siswa juga kebingungan untuk menyampaikan bagaimana menentukan tinggi dan luas tower ketiga pada saat wawancara. Ketika wawancara siswa hanya menyampaikan bahwa untuk mencari panjang dan lebar dapat menggunakan metode eliminasi dari sistem persamaan linier dua variabel. Untuk membuat alasan dari penyelesaian yang telah dibuat siswa juga tidak paham, hal ini diakibatkan karena siswa belum memahami soal dengan benar sehingga siswa merasa kesulitan dalam membuat alasan dari penyelesaian masalah. Siswa juga tidak bisa menarik kesimpulan dari penyelesaiannya meskipun siswa ini mendapatkan hasil dari luas tower ketiga. Hal ini menunjukkan bahwa siswa hanya menyelesaikan masalah tanpa memikirkan penyelesaian yang tepat. Berdasarkan hasil analisis yang telah dibuat, maka dilakukan pembahasan untuk setiap indikator kemampuan penalaran matematis pada siswa yang berkemampuan tinggi, sedang, dan rendah sebagai berikut.

\section{Indikator Mengajukan Dugaan}

Berdasarkan data hasil tes dan wawancara menunjukkan bahwa siswa yang berkemampuan matematis tinggi dan siswa yang memiliki kemampuan matematis sedang sudah mampu untuk mengajukan dugaan dengan baik. Siswa yang berkemampuan matematis tinggi sudah mampu menyampaikan informasi yang diketahui dan ditanyakan pada soal secara tertulis dan lisan dengan baik. Siswa juga sudah mampu untuk membuat prosedur perencanaan untuk menyelesaikan masalah matematika. Siswa yang memiliki kemampuan matematis sedang dapat membuat prosedur perencanaan yang akan dilakukan untuk menyelesaikan suatu soal berdasarkan pengalaman yang dimiliki. Jadi, untuk indikator penalaran matematis mengajukan dugaan, siswa sudah dapat bernalar sesuai dengan indikator yang telah ditentukan. Sedangkan siswa dengan kemampuan matematis 
rendah masih kesusahan dan menyampaikan informasi yang terdapat pada soal secara terbata-bata dan tidak runtut. Akibatnya siswa tidak dapat mengajukan dugaan dengan baik. Dugaan yang dibuat oleh siswa masih terlalu awam dan tidak membantu siswa dalam menyelesaikan masalah.

Penelitian ini juga sejalan dengan penelitian (Mualifah, 2014) yang menyatakan bahwa siswa yang berkemampuan matematika tinggi berhasil melakukan dugaan dengan dapat menyebutkan informasi-informasi yang tersedia dalam soal, untuk siswa yang berkemampuan matematika rendah tidak dapat menyusun dugaan kerena tidak dapat menyusun informasi sehingga tidak dapat menyelesaiakn masalah. Hal ini juga sesuai dengan pernyataan (Ario, 2016) yang mengatakan bahwa pemahaman konsep harus menjadi prioritas dalam pembelajaran karena menjadi modal utama untuk dapat memiliki kemampuan penalaran matematis. Jadi siswa harus memahami konsep matematika terlebih dahulu agar siswa dapat memecahkan suatu permasalahan matematika.

\section{Indikator Melakukan Manipulasi Matematika}

Berdasarkan data dari hasil penelitian yang sudah di parkan sebelumnya, siswa yang memiliki kemampuan matematis tinggi mampu melakukan manipulasi matematika untuk memecahkan masalah dengan baik. Siswa dengan kemamuan matematis sedang masih melakukan kesalahan dalam menuliskan perhitungan, siswa juga masih menuliskan perhitungan dalam bentuk kalimat biasa bukan dalam bentuk kalimat matematika. Hal ini terlihat dari cara siswa berkemampuan matematis tinggi dan siswa yang berkemampuan matematis sedang dalam menyusun rencana penyelesaian. Hal ini juga sesuai dengan apa yang dikatakan oleh (Ario, 2016) bahwa kesalahan siswa dalam indikator memanipulasi matematika salah satunya adalah salah perhitungan. Sedangkan siswa yang memiliki kemampuan matematis rendah belum mampu melakukan manipulasi matematika dengan baik. Siswa dengan kemamuan matematis tinggi dan sedang sudah mamu menyelesaikan soal yang diberikan dengan cara yang runtut dan sesuai sedangkan siswa dengan kemamuan matematis rendah masih belum mampu menyelesaikan soal yang diberikan dengan runtut dan sesuai dan cenderung mengerjakan dengan asal. Sesuai dengan penelitian yang dilakukan (Ardhiyanti, 2019) menyatakan bahwa hanya siswa berkemampuan matematis tinggi dan sedang yang dapat memenuhi indikator melakukan manipulasi matematika sedangkan siswa yang berkemampuan matematis rendah tidak mampu melakukan manipulasi matematika.

\section{Indikator Memberikan Pernyataan Logis}

Berdasarkan penelitian yang dilakukan didapatkan data bahwa dalam memberikan pernyataan yang logis dari pekerjaannya hanya siswa dengan kemampuan penalarn matematis tinggi yang mampu melakukannya, sedangkan siswa dengan kemampuan matematis sedang sudah bisa namun terbatabata dalam memberikan alasannya. Hal ini sejalan dengan (Melin, 2015) bahwa siswa yang memiliki kemampuan memberikan pernyataan yang logis untuk membuktikan suatu argumen dapat membuktikan kebenaran jawaban yang diperoleh dengan menggunakan cara tertentu. Siswa dengan kemampuan matematis rendah juga belum mampu memberikan alasan dan bukti dari solusi yang telah dibuat. Menurut penelitian yang telah dilaksanakan, siswa belum bisa memberikan alasan adalah 
Kemampuan Penalaran Matematis Siswa dalam Memecahkan Masalah Matematika pada Saat Pembelajaran Daring, Nastiti Kusumaningtyas, I. Nengah Parta, Hery Susanto

karena siswa belum memahami soal dengan baik. Kurangnya siswa dalam mengartikan suatu permasalahan menyebabkan penyelesaian yang dilakukan juga kurang tepat. Sehingga siswa belum mampu memberikan alasan yang sesuai dengan model, fakta dan memeriksa jawaban yang telah ditentukan. Terbukti juga bahwa soal meminta siswa selain mencari tinggi tower ketiga juga mencari luas dari tower ketiga tetapi siswa hanya mencari tinggi tower tanpa mencari luas tower.

Kesalahan siswa dalam memeriksa kebenaran dari pendapatnya disebabkan karena siswa melakukan kesalahan dalam memanipulasi matematika dan siswa juga belum mampu menggunakan cara yang lain dalam menyelesaikan soal sehingga siswa belum bisa mengembangkan pola atau sifat tersebut ke dalam kalimat matematika.

\section{Indikator Menarik Kesimpulan}

Berdasarkan hasil penelitian yang telah diaparkan, siswa dengan kemampuan penalaran matematis tinggi sudah mampu untuk menarik kesimpulan. Siswa langsung bisa menyampaikan kesimpulan yang didapatnya setelah menyelesaikan soal ketika dilakukan wawancara. Sehingga dapat disimpulkan bahwa siswa yang memiliki kemampuan matematis tinggi sudah dapat mencapai indikator penalaran menarik kesimpulan dan membuat generalisasi. Hal ini sesuai dengan pendapat (Nur Fitri, 2015) yang menyatakan bahwa menarik kesimpulan atau membuat generalisasi dapat dilihat dari kemampuan siswa membuat kesimpulan berdasarkan pernyataan yang telah dibuktikan kebenarannya. Sedangkan siswa dengan kemampuan matematis sedang masih merasa kebingungan sehingga perlu dibantu oleh peneliti ketika menarik kesimpulan.

Siswa yang berkemampuan matematis rendah tidak bisa untuk menarik kesimpulan dari suatu penyelesaian. Penyebab siswa belum mampu menarik kesimpulan dari suatu penyelesaian adalah karena siswa melakukan kesalahan dalam menyajikan pernyataan matematika secara tertulis, dan salah dalam melakukan manipulasi matematika.

\section{KESIMPULAN}

Siswa dengan kemampuan matematis tinggi sudah bisa mengajukan dugaan mengenai permasalahan pada soal. Siswa bisa memahami soal dengan baik, dan membuat model matematika yang sesuai serta sudah bisa untuk memanipulasi soal. Berdasarkan jawaban yang diberikan, siswa ini sudah bisa memberikan bukti kebenaran dari jawabannya. Kemampuan menarik kesimpulan siswa ini lebih bagus daripada siswa dengan kemampuan matematis sedang meskipun saat menarik kesimpulan masih sedikit dibantu oleh peneliti. Siswa dengan kemampuan akademik sedang sudah bisa untuk mengajukan dugaan mengenai permasalahan pada soal. Siswa juga sudah bisa untuk melakukan manipulasi matematika namun siswa masih bingung tentang operasi yang digunakan. Siswa dengan kemampuan matematis sedang bisa untuk memberikan kebenaran dari argumen yang digunakan dibantu dengan peneliti. Untuk menarik kesimpulan, siswa cenderung membacakan permintaan soal digabung dengan jawaban yang diperolehnya. Siswa dengan kemampuan matematis rendah masih belum bisa untuk mengajukan dugaan untuk mengerjakan soal. Karena siswa belum bisa mengajukan 
dugaan yang sesuai sehingga siswa merasa kesulitan untuk melakukan manipulasi matematika. Siswa juga masih belum ialah untuk membuktikan kebenaran dari argumen yang telah digunakanya. Untuk menarik kesimpulan, siswa masih merasa kesulitan dan cenderung untuk menyebutkan hasil akhir yang dia bisa saja.

\section{UCAPAN TERIMA KASIH}

Penulis mengucapkan syukur kepada Allah SWT yang memberikan kelancaran dalam menyelesaikan penelitian dan artikel ini. Saya juga mengucapkan terimakasih kepada orang tua dan keluarga yang memberikan dukungan secara mental. Rasa terimakasih juga tidak lupa diucapkan kepada Dr. I Nengah Parta, M.Si. dan Dr. Hery Susanto, M.Si. selaku pembimbing tesis saya. Tidak lupa juga saya ucapkan terimakasih kepada guru dan siswa dari SMP Negeri 1 Kencong yang memberikan kesempatan untuk melakukan penelitian di sekolah tersebut.

\section{REFERENSI}

A. Hidayat, C. S. (2019). Proses Berpikir Siswa Field Dependent dalam Menyelesaikan Masalah Geometri Berdasarkan Tahapan Polya. Jurnal Pendidikan : Teori, Penelitian, dan Pengembangan, 4(7), 923-937.

Abdurrahman, S. (1999). Metode Penelitian Suatu Pemikiran dan Penerapan. Jakarta: PT. Rineka CIpta.

Ardhiyanti, E. (2019). Deskripsi Kemampuan Penalaran dalam Pemecahan Masalah Matematika pada Materi Aritmatika Sosial. Cendekia, 3 (1).

Arikunto, S. (2013). Prosedur Penelitian : Suatu Pendekatan Praktik. Jakarta: Rineka Cipta.

Ario, M. (2016). Kemampuan Penalaran Matematis Siswa SMK Setelah Mengikuti Pembelajaran Berbasis Masalah. Educational Research, 5(2), 125-134.

Creswell, J. W. (2012). Educational Research : Planning, Conducting, and Evaluating Quantitative and Qualitative Research (4th ed.). Boston: Pearson Education Inc.

E. Rohaeti, B. M. (2019). Pengembangan Media Visual Basic Aplication untuk Meningkatkan Kemampuan Penalaran Siswa SMP dengan Pendekatan Open Ended. Supremum Journal of Mathematics Education, 3(2), 95-108.

Hidayat W., H. I. (2018). Adversity Quotient (AQ) dan Penalaran Kreatif Matematis Mahasiswa Calon Guru. Jurnal Elemen, 4, 230-242.

Melin, K. (2015). Profil Kemampuan Penalaran Siswa Dalam Memecahkan Masalah Soal Cerita Barisan dan Deret Aritmatika di Kelas X SMA Negeri 2 Palu. Jurnal Pendidikan Matematika , 4(2).

Mualifah, A. N. (2014). Profil Penalaran Siswa dalam Pemecahan Masalah Open Endd Ditinjau dari Kemampuan Matematika. MATHEdunesa, 3(1).

Muharrom, T. (2014). Pengaruh Pembelajaran Dengan Model Kooperatif Tipe Student Teams 
Kemampuan Penalaran Matematis Siswa dalam Memecahkan Masalah Matematika pada Saat Pembelajaran Daring,

Achievement Division (STAD) Terhadap Kemampuan Penalaran Dan Komunikasi Matematik

Peserta Didik Di SMK Negeri Manonjaya Kabupaten Tasikmalaya. Jurnal Pendidikan dan Keguruan, 1(1), 1.

NCTM. (2000). Principles and Standards for School Mathematics. USA: The National Council of Teacher of Mathematics Inc.

Nur Fitri, B. H. (2015). Meningkatkan Kemampuan Penalaran Siswa dengan Wawancara Klinis pada Pemecahan Masalah Aritmetika Sosial Kelas VIII SMP. Jurnal Pendidikan dan Pembelajaran Khatulistiwa, 4(5).

Nurkhaeriyah T. S., E. R. (2018). Analisis Kemampuan Penalaran Matematis Siswa MTS di Kabupaten Cianjur pada Materi Teorema Pythagoras. JPMI (Jurnal Pembelajaran Matematika Inovatif, 1(5), 827. doi:https://doi.org/10.22460/jpmi.vli5.p827-836

Parta, I. N. (2016). Karakteristik Berpikir Analitik Mahasiswa dalam Memrcahkan "Masalah Sederhana". Malang: Seminar Nasional Pendidikan Matematika Pascasarjana UM. doi:https://doi.org/10.13140/RG

Polya, G. (1973). How to Solve It: A New Aspect of Mathematical Method (Second Edition). New Jersey: Princeton University Press.

Salmina, M. (2018). Kemampuan Penalaran Matematis Siswa Berdasarkan Gender pada Materi Geometri. Jurnal Numeracy, 5(1), 41-48.

Suciati, D. (2015). Profil Kemampuan Penalaran Siswa dalam Memecahkan Masalah Aritmetika Sosial. Jurnal Pendidikan Matematika, 3(1), 46. 